\title{
진동시험을 이용한 원자력발전소 캐비닛 구조의 지진응답예측기법 Seismic Response Prediction Method of Cabinet Structures
in a Nuclear Power Plant Using Vibration Tests
}

\author{
구기영' ${ }^{1)}$ 취진타오 ${ }^{2)} \cdot$ 조성국 ${ }^{3)} \cdot$ 김두기 $^{4)}$ \\ Koo, Ki-Young $\cdot$ Cui, Jintao $\cdot$ Cho, Sung Gook $\cdot$ Kim, Dookie
}

\begin{abstract}
국문 요약 >> 본 연구는 원자력발전소에 설치되는 캐비닛형 전기기기의 동적 진동시험 자료를 이용하여 캐비닛의 지진응답을 예측할 수 있는 기법을 제안하였다. 제안된 기법은 1) 절점질량 이상화 모델에 기반한 등가 지진하중 산정, 2) 진동시험자료에 기반한 캐비닛 구조의 입출력 상태방정식 규명, 3) 산정된 등가지진하중과 규명된 입출력 상태방정식을 사용한 지진응답산정의 과정으로 구성된다. 제안 된 기법은 유한요소기법(FEM) 모델 개선(Model Updating)에 기반한 지진응답예측기법에 비하여 모델링 오차가 개입 되지 않는 장점을 가진다. 캐비넷 구조를 이상화한 2 차원 프레임 모델과 3 차원 상세 모델에 대한 수치검증을 통하여 제안된 기법이 지진응답을 매우 정확하 게 예측을 함을 관찰하였고, 측정 노이즈에 대해서도 강인함을 관찰하였다. 추후연구로 실험검증이 요구된다.
\end{abstract}

주요어 지진응답예측, 캐비닛 구조, 충격진동시험, 상태방정식

\begin{abstract}
This paper presents a seismic response prediction method using vibration tests of cabinet-type electrical equipment installed in a nuclear power plant. The proposed method consists of three steps: 1) identification of earthquake-equivalent forces based on lumped-mass system idealization, 2) identification of a state-space-equation model relating input-output measurements obtained from the vibration tests, 3) seismic prediction using the identified earthquake-equivalent forces and the identified state-space-equation. The proposed method is advantageous compared to other methods based on FEM (finite element method) model update, since the proposed method is not influenced by FEM modeling errors. Through a series of numerical verifications on a frame model and 3-dimensional shell model, it was found that the proposed method could be used to accurately predict the seismic responses, even under considerable measurement noise conditions. Experimental validation is needed for further study.
\end{abstract}

Key words seismic response prediction, cabinet structures, vibration tests, subspace identification method

\section{1. 서 론}

원자력발전소에는 전기기기 혹은 제어계측장비를 수용하 는 수많은 철재 캐비닛들이 설치되어 있다. 이들 중 대부분 은 발전소의 안전한 운전과 정지 기능을 담당하는 중요 설 비들로서 설계지진과 같은 강한 지진 시에도 구조적인 건전 성을 유지해야 함은 물론이고 각각에 부여된 고유의 기능을

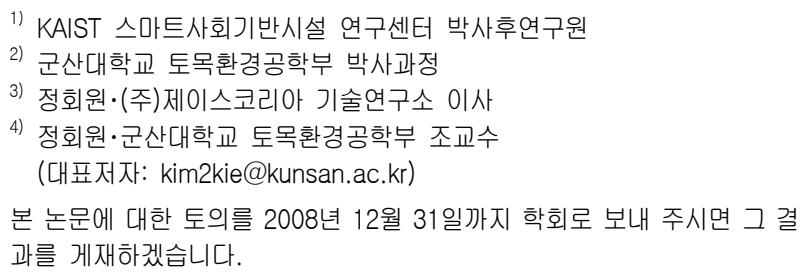

(논문접수일 : 2008. 8. 21 / 수정일 : 2008. 9. 24 / 게재확정일 : 2008. 9. 24)
오류 없이 원활히 수행해야 한다. 이를 위해 발전소가 건설 된 당시에 구조물들은 내진설계를 통하여 내진안전성이 확 보되고, 구조물 내부에 설치되는 중요 기기와 설비들은 내 진검증(Seismic Qualification)을 통하여 내진안전성이 입 증된다.

미국에서 원자력발전소(이하 원전)의 상업운전은 1960년 대 초반부터 시작되었으며, 국내의 경우에도 1970년대 후반 부터 원전을 건설하여 가동하고 있다. 이 산업 분야에서 40 년 이상의 기간 동안에 얻은 경험을 토대로 현재는 초창기 에 비하여 훨씬 진보된 설계 기술을 보유하게 되었고, 인허 가 요건도 강화되었다. 1970년대부터 미국에서는 현행 내진 수준과 대등한 요건을 갖기 이전에 건설된 오래된 원전들에 설치된 기기들의 내진안전성을 재평가할 필요성을 인식하 고, 이 사안을 USI A-46로 공식 제기하였다. ${ }^{(5-7)}$ 
국내에서는 고리1, 2호기와 월성1호기가 USI A-46 문제 의 대상에 포함되므로 현재 이 원전들을 대상으로 현행 기 준과 요건을 적용하여 구조물과 기기들의 내진안전성을 재 평가하고 성능을 향상시키는 작업이 수행중이다. 이 중에서 구조물들은 설계도를 근간으로 해석모델을 작성하고 지진 응답해석을 통하여 내진성능이 평가될 수 있다. 반면에 기 기들은 진동시험 혹은 지진응답해석을 통하여 내진성이 입 증될 수 있다. 그러나 가동 중인 원자력발전소에 설치된 기 기는 진동시험 등의 목적으로 외부로 반출하는 것이 허용되 지 않으며, 지진응답해석을 위한 동적해석모델의 작성도 용 이하지 않다.

통상 원전의 계전기 등을 포함한 전기기기의 내진성능은 진동대시험을 통해 결정되며, 이 시험에서 일반적으로 계전 기는 진동대 상에 직접 장착된다. 계전기에 대한 지진요구 도는 일반적으로 계전기가 장착된 캐비닛 밑면에서의 층응 답스펙트럼으로 나타낼 수 있다. 계전기에 대한 지진요구도 와 이에 상응하는 성능값을 구하기 위해, 계전기 장착 위치 에서 캐비닛으로 인한 층운동의 증폭이 필요하며, 이를 통 해 계전기의 내진 허용성을 평가할 수 있다. ${ }^{(8),(9)}$

원전 내부 전기기기의 내진안전성을 진단하기 위해서는 이들에 대한 동특성을 먼저 분석하여야 한다. 특히, 기존에 설치되어 운용 중인 기기의 전부 혹은 일부 부품을 교환하 는 경우에도 부품 교체 이전과 이후에도 모두 내진성능 요 건을 충족하는지를 입증하여야 하므로, 이 경우에도 기기의 동특성분석 작업이 우선적으로 요구된다. ${ }^{(1-4),(13-17)}$

그러나 원전의 성분들 중에서 캐비닛 혹은 패널 등과 같 은 전기 기기들은 설비 자체의 구조적인 특성뿐만 아니라, 내부에 포함된 부품들의 연결도 매우 복잡하기 때문에, 이 러한 설비의 강성과 기여 질량을 정확히 판단하는 것이 매 우 어렵다. 즉, 이런 종류의 설비들은 동적해석모델을 정확 하게 구축하기가 어려우므로, 기존의 해석에 의한 방법으로 그들의 동특성을 파악하는 것이 용이하지 않은 실정이다.

본 연구에서는 실제로 진동대 실험을 통한 내진성능평가 가 어려운 원전 설비 캐비닛에 대하여, 고비용 수학적 모델 링과 해석을 사용하지 않고 일반적으로 현장에서 적용할 수 있는 방법으로써 충격해머 테스트 기반의 진동시험을 이용 한 지진응답예측기법을 제안하였다.

\section{2. 캐비닛 구조물의 지진응답예측기법}

지진하중에 대한 캐비닛 동적 거동의 지배방정식은 다음 과 같다.

$$
M \ddot{u_{r}}+C \dot{u_{r}}+K u_{r}=-M\{1\} \ddot{u_{g}}
$$

여기서 $M, C, K$ 는 캐비닛의 질량, 감쇠, 및 강성행렬이고, $u_{r}$ 은 캐비닛 하단 슬래브변위에 대한 캐비닛의 상대변위 열 벡터, $\{1\}$ 은 1 로 채워진 열 벡터, $\ddot{u}_{g}$ 는 지진가속도이다. 식 (1)에서 보는 바와 같이, 캐비닛의 지진응답은 지진등가 입 력하중 $-M\{1\} \ddot{u_{g}}$ 이 가해졌을 때의 구조계의 응답으로 표현 된다. 이때, 질량행렬 $M$ 은 캐비닛과 내부설비의 설계도를 바탕으로 추정된 값을 사용한다.

입력하중에 대한 구조계 응답의 입출력 관계는 진동시험 을 통해 계측된 가진력과 응답가속도에 대하여, 다음과 같 은 이산시간 상태방정식을 규명할 수 있다.

$$
\begin{gathered}
x(k+1)=\boldsymbol{A} x(k)+\boldsymbol{B} u(k)+\boldsymbol{K} e(k) \\
\boldsymbol{y}(k)=\boldsymbol{C} x(k)+\boldsymbol{D} u(k)+e(k)
\end{gathered}
$$

여기서, $u(k), y(k), e(k), x(k)$ 는 각각 $k$ 번째 타임스텝 $(k=1,2, \ldots, N ; N$ 은 측정 포인트 개수)에서의 충격진동 가 진력 열 벡터, 응답가속도 열 벡터, 측정 노이즈 열 벡터, 상 태(State) 열 벡터이고 $A, B, C, D, K$ 는 시스템 행렬이다. 이산시간 상태방정식 규명기법은 반복법인 예측오차법 (Prediction Error Method)과 비반복법인 부공간규명기법 (Subspace Identification Method) 등을 이용할 수 있으나, 본 연구에서는 계산시간이 짧고, 수렴성이 좋은 부공간규명 기법을 사용하였다.

식 (1)의 우변의 지진등가 입력하중 $-M\{1\} \ddot{u}_{g}$ 을 진동시 험을 통해 규명된 식 (2)와 같은 이산시간 상태방정식의 입 력 $u(k)$ 에 대입하면, 캐비닛의 지진 가속도 응답을 예측할 수 있으며, 전체 과정은 표 1 과 같이 요약 될 수 있다.

\section{3. 부공간규명기법}

부공간규명기법(Subspace Identification Methods)은 시 스템 입출력으로부터 식 (2)와 같은 상태방정식을 추정하는 기법으로써, 전통적인 시스템 규명이론의 문제점과 한계를 극 복한 지난 15 년간의 최신 이론이다. 예측오차기법 (Prediction Error Method)과 같은 전통적인 기법들은 예측에러의 최소 자승에 기반하여 시스템 행렬을 추정하는데, 이 과정에서 비선형 최적화와 관련된 반복수행과, 이와 관련된 수렴성의 문제 등을 야기시킨다. 또한, 계산상에서 도입되는 여러 가지 사용자 선택사항(Options)에 따라 결과가 달라지는 단점을 가 진다. 반면, 부공간규명기법은 입출력관계로부터 Kalman state를 구하고, 선형 최소자승문제를 풀어서 시스템 행렬을 
〈표 1〉 캐비닛 지진응답예측 과정

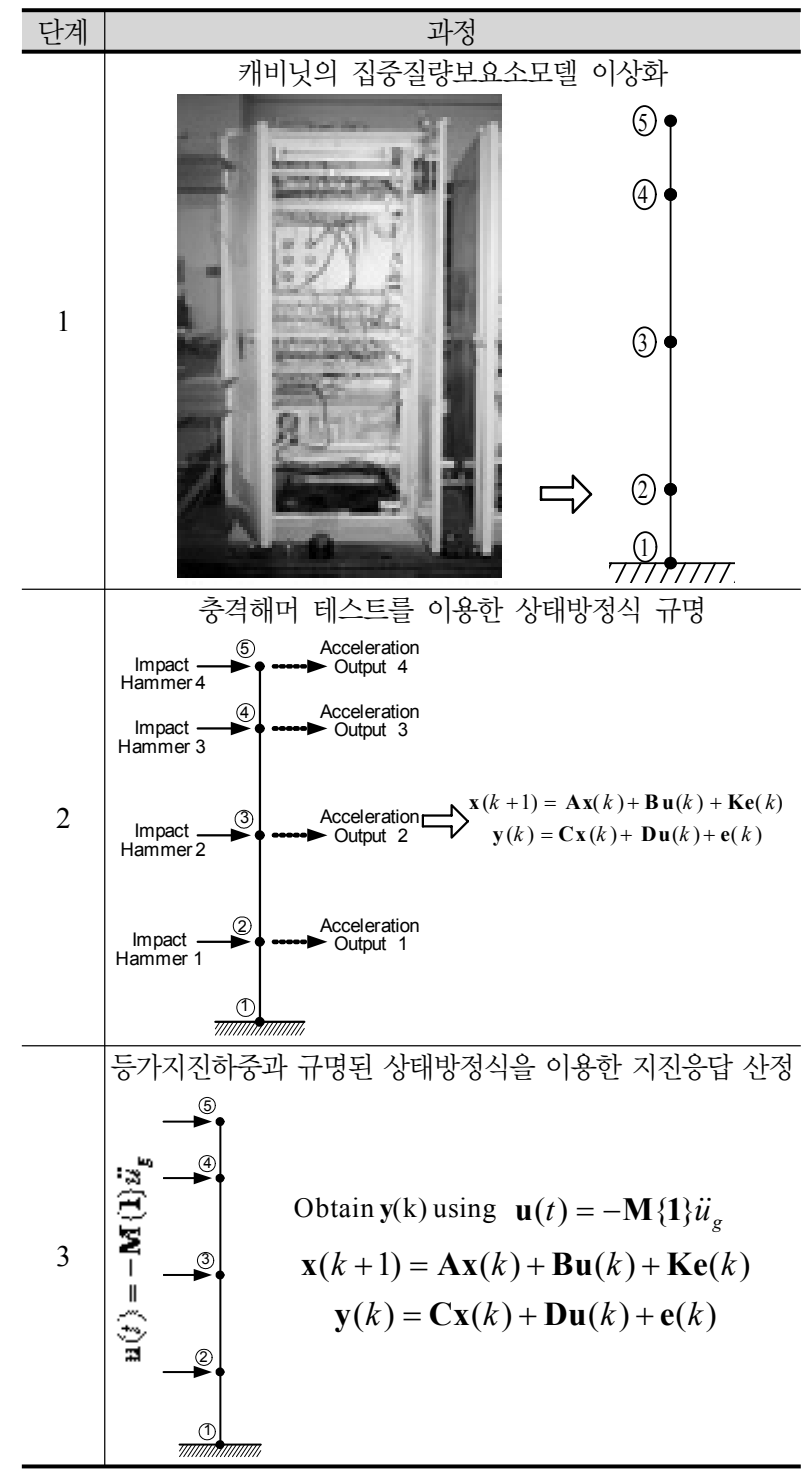

반복계산(Iteration) 없이 구할 수 있다. 또한, 부공간규명기 법에서의 단하나의 선택사항은 시스템 차수(Order) 뿐이다. 유도(Derivation)방법은 다수가 존재하고 복잡한 편이어서, 본 논문에서는 개략적으로 유도과정을 설명하도록 한다(자 세한 유도과정은 Ljung(1999) ${ }^{(11)}$ 참조).

부공간규명기법에서의 상태벡터는 다음과 같이 과거 입 출력의 선형조합으로 다음과 같이 정의된다.

$$
\begin{aligned}
& p(k)=\left[y^{T}(k-1) \ldots y^{T}(k-N), u^{T}(k-1) \ldots u^{T}(k-N)\right]^{T} \\
& x(k)=J p(k)
\end{aligned}
$$

여기서, $p(k)$ 는 $\operatorname{lag}$ 값 $N$ 에 의하여 그 크기가 결정되는 과거 $k$ 번째 샘플이고, 행렬 $J$ 는 과거 계측입출력으로부터 추정 되는 값이다. 만약, 행렬 $\boldsymbol{J}$ 가 결정되면, 상태벡터 $\boldsymbol{x}(k)$ 가 식 (4)로부터 계산되어질 수 있고, 또한, 다음과 같이 시스템
행렬 $A, B, C, D$ 를 결정할 수 있다.

$$
\begin{array}{r}
{\left[\begin{array}{c}
\hat{A} \hat{B} \\
\hat{C} \hat{D}
\end{array}\right]=\operatorname{cov}\left(\left[\begin{array}{c}
x(k+1) \\
\boldsymbol{y}(k)
\end{array}\right],\left[\begin{array}{l}
\boldsymbol{x}(k) \\
\boldsymbol{u}(k)
\end{array}\right]\right)} \\
\times \operatorname{cov}^{-1}\left(\left[\begin{array}{l}
\boldsymbol{x}(k) \\
\boldsymbol{u}(k)
\end{array}\right],\left[\begin{array}{l}
\boldsymbol{x}(k) \\
\boldsymbol{u}(k)
\end{array}\right]\right)
\end{array}
$$

부공간규명기법들은 다음과 같은 특이치 분해(Singular Value Decomposition)을 수행하여 행렬 $J$ 를 정한다.

$$
\operatorname{svd}\left(W_{1} \operatorname{cov}(\tilde{f}, p) W_{2}\right)=\left[\begin{array}{ll}
U_{1} & U_{2}
\end{array}\right]\left[\begin{array}{cc}
S_{1} & 0 \\
0 & S_{2}
\end{array}\right]\left[\begin{array}{c}
V_{1}^{T} \\
V_{2}^{T}
\end{array}\right]
$$

여기서, $W_{1}, W_{2}$ 는 가중치행렬이고, $\tilde{f}$ 는 현재의 계측에 기 반한 미래 예측 값이고, $p$ 는 과거 계측치이다.

부공간규명기법은 행렬 $J$ 를 계산하기 위하여 모든 특이 치(Singular Value) 들을 사용하는 대신, 크기가 큰 상위 특 이치에 해당하는 $U_{1}$ 과 $S_{1}$ 을 사용한다. 이것이 부공간규명 기법이라는 이름으로 불리는 이유이다. 시스템의 차수는 특 이치행렬 $S_{1}$ 의 크기(Dimension)과 같은데, 특이치행렬의 대각성분 $\operatorname{diag}\left(\left[\boldsymbol{S}_{1}, \boldsymbol{S}_{2}\right]\right)$ 을 도시하였을 때, 특이치가 갑작스 럽게 감소하기 직전의 차수로 결정될 수 있다. 이를 통하여 크기가 큰 상위 특이치들의 효과를 모두 포함하는 시스템 모델을 만들 수 있다.

부공간규명기법들은 가중치 행렬 $W_{1}, W_{2}$ 을 정하는 방식 에서 서로 차이를 보이는데, N4SID(Subspace State Space System Identification) ${ }^{(10)}$ 는 $W_{1}=I$ 을 사용하며, 다른 방법 에 비하여 연산시간이 비교적 적게 걸리는 장점이 있다. 그 외에도 MOESP(Multivariable Output Error State Space), $\mathrm{CVA}$ (Canonical Variate Analysis) 등의 여러 가지 변종들 이 존재한다.

\section{4. 수치 검증}

\section{1 프레임 모델}

수치검증을 위하여 그림 1 좌측의 프레임 모델에 대한 El Centro 지진응답 예측을 수행하였다. 충격진동시험를 모사 하기 위하여 상용 유한요소 프로그램 $\mathrm{MIDAS}^{(12)}$ 를 사용하 여 절점 2 5에 충격하중(Impact Load)을 가했을 때의, 각 절점에서의 가속도응답 신호를 그림 3 와 같이 생성하였다. 입출력관계로부터 이산시간상태방정식을 추정하기 위하여 부공간규명기법의 일종인 N4SID 기법을 이용하였다. 상태 방정식의 차수는 3절에서 설명한 바와 같이 그림 4의 특이 치가 갑작스럽게 감소하기 직전의 order=8 선택하였고, 최 종적으로 규명된 상태방정식은 그림 5에 보는 바와 같이 계 


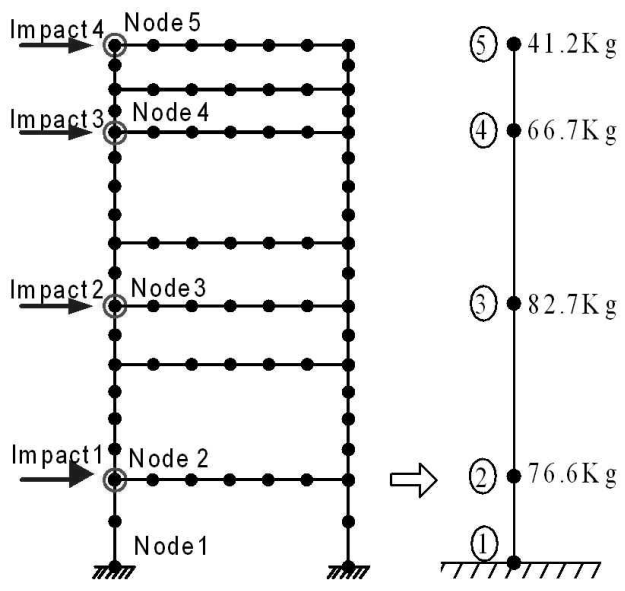

〈그림 1〉 프레임 모델과 지진하중 산정을 위한 절점질량 이상화 모델

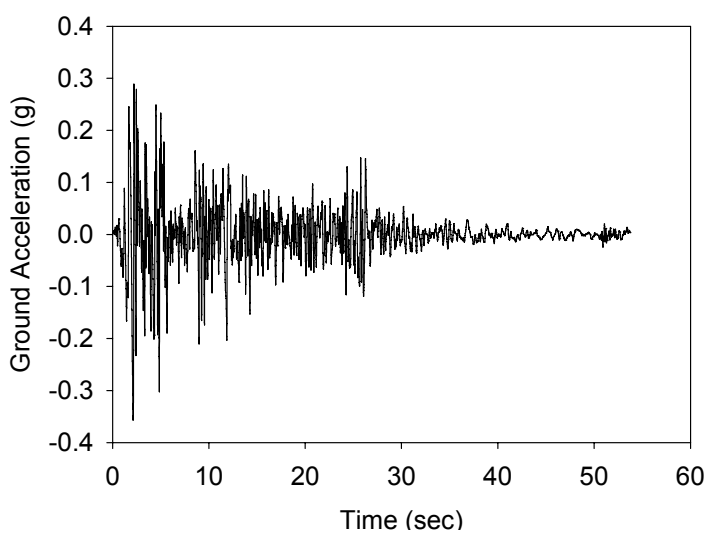

〈그림 2〉El Centro 지진 가속도 시계열
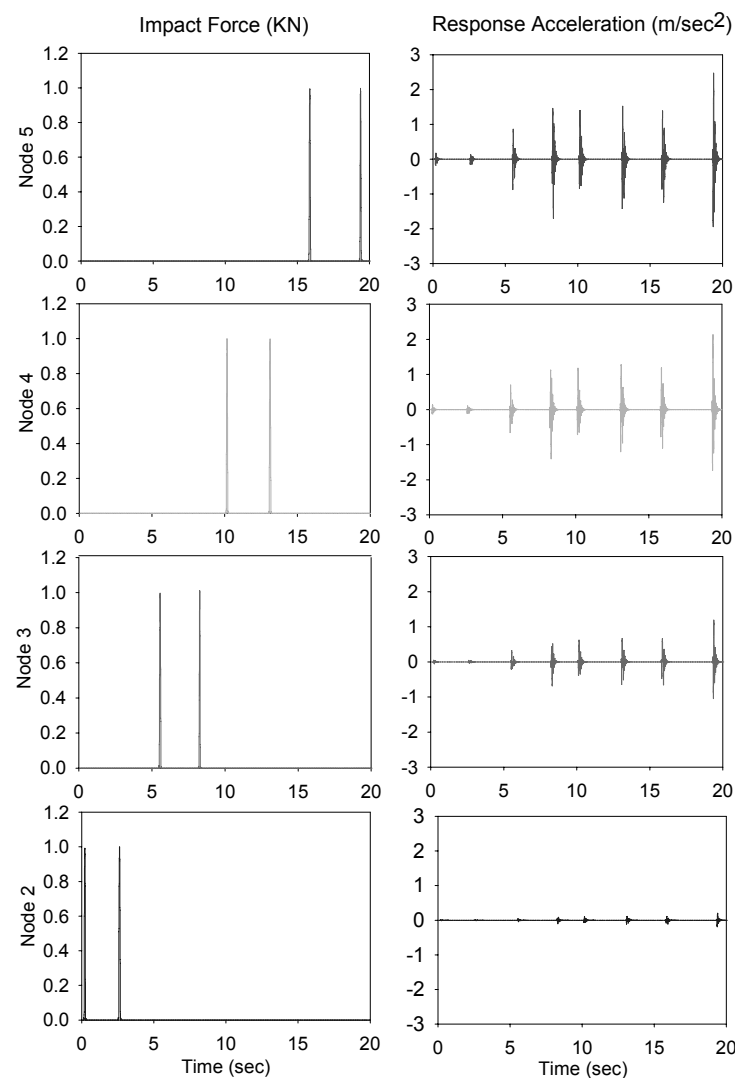

〈그림 3〉 프레임 모델에 대한 충격해머와 가속도응답 신호

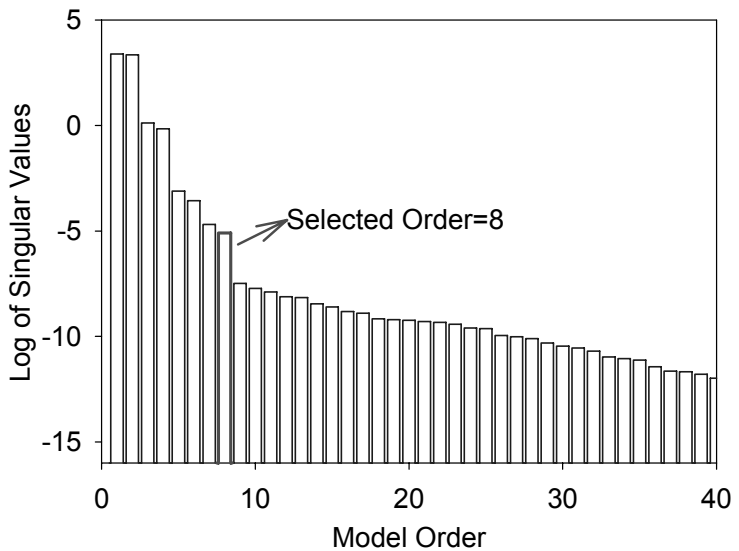

〈그림 4〉상태방정식 차수 결정
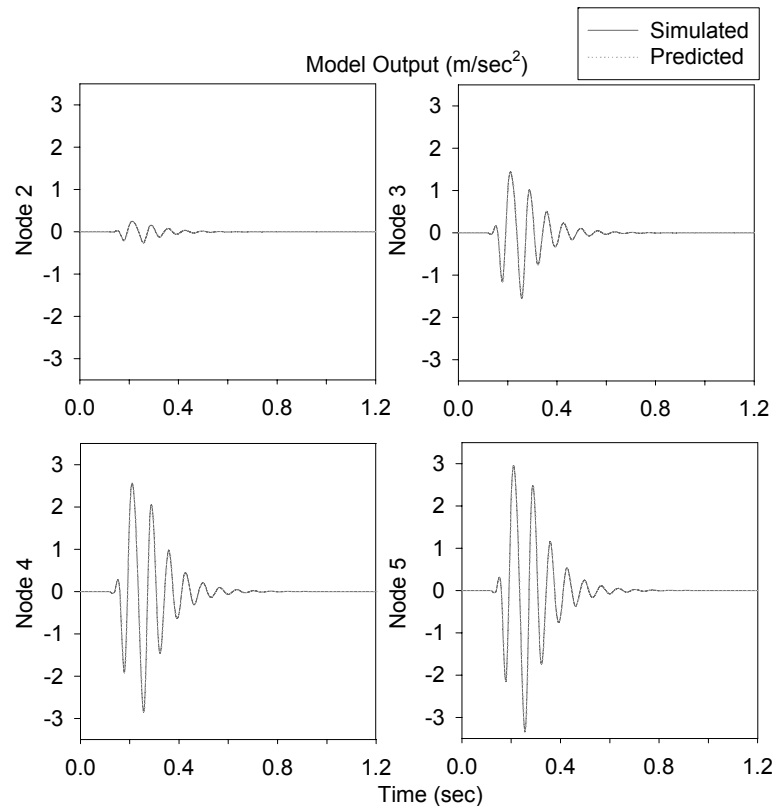

〈그림 5〉 규명된 이산시간 상태방정식의 적합도

측된 입출력 관계를 매우 정확하게 재현하고 있음을 알 수 있었다.

그림 1 좌측의 프레임 모델에 대하여 질량 행렬 $M$ 을 구 하기 위하여 절점질량 이상화 모델을 산정하면 그림 1 우측 과 같다. 등가지진하중 $u(t)=-\boldsymbol{M}\{1\} \ddot{u}_{g}$ 을 산정하고, 규명 된 상태방정식의 입력으로 사용하면 프레임 모델의 가속도 응답을 추정할 수 있으며 이를 참값과 비교하면 그림 6과 같다. 제안된 기법이 실제 지진응답을 전 시간영역에서 매 우 정확하게 예측하고 있음을 알 수 있다.

\subsection{3차원 유한요소모델}

수치검증을 위하여 그림 7 좌측의 3차원 유한요소모델에 대한 El Centro 지진응답 예측을 수행하였다. 충격진동시험 를 모사하기 위하여 상용 유한요소 프로그램 $\mathrm{MIDAS}^{(12)}$ 를 사용하여 절점 2 5에 충격하중(Impact Load)을 가했을 때 

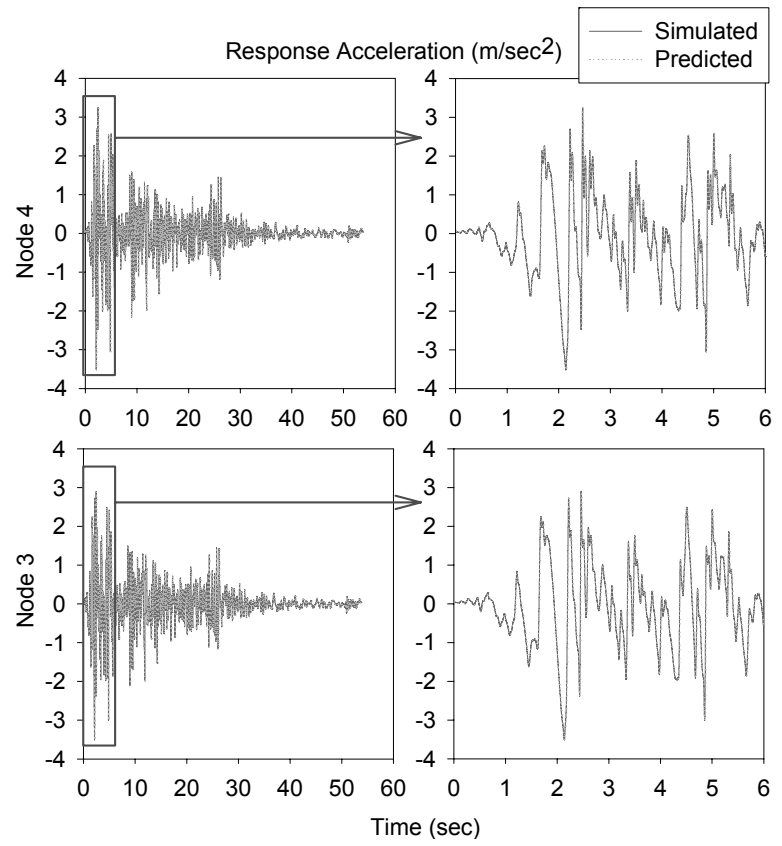

〈그림 6〉제안된 방법으로 추정된 프레임 모델의 지진응답

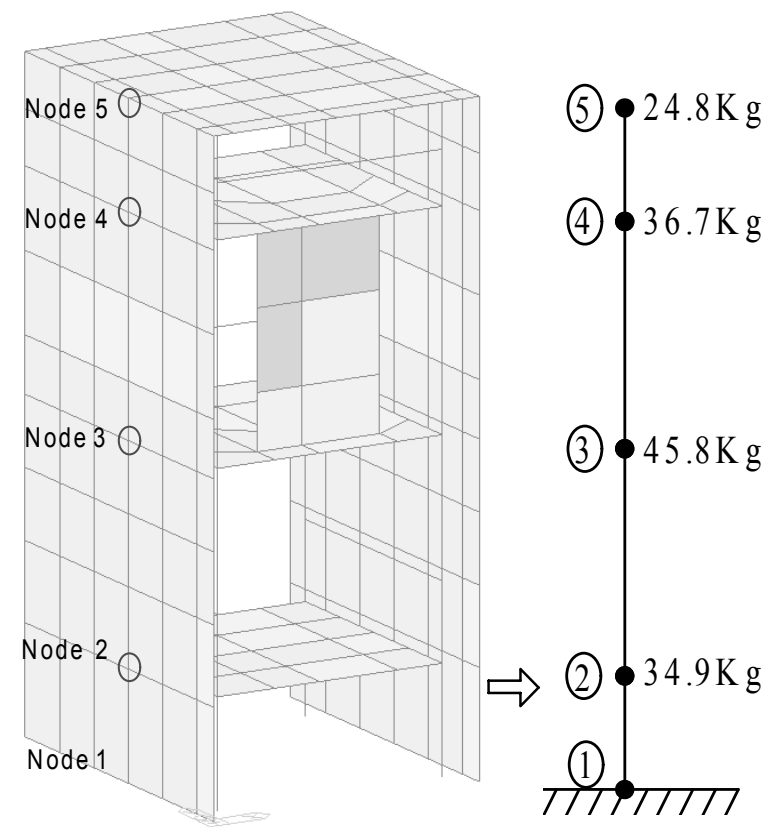

〈그림 7〉 3차원 유한요소모델과 지진하중 산정을 위한 절점질량 이상 화 모델

의, 각 절점에서의 가속도응답 신호를 그림 9 와 같이 생성하 였다. 프레임 모델과 마찬가지로 N4SID 기법을 이용하였 고, 상태방정식의 차수는 그림 8 에서 보는 바와 같이 8 로 정 하였으며, 최종적으로 규명된 상태방정식은 그림 10에 보는 바와 같이 계측된 입출력 관계를 매우 정확하게 재현하고 있음을 알 수 있었다.

등가지진하중 산정을 위한 절점질량 이상화 모델은 그림 그림 7 우측과 같으며, 등가지진하중을 상태방정식의 입력 으로 사용한 가속도응답과 참값과 비교하면 그림 11 과 같

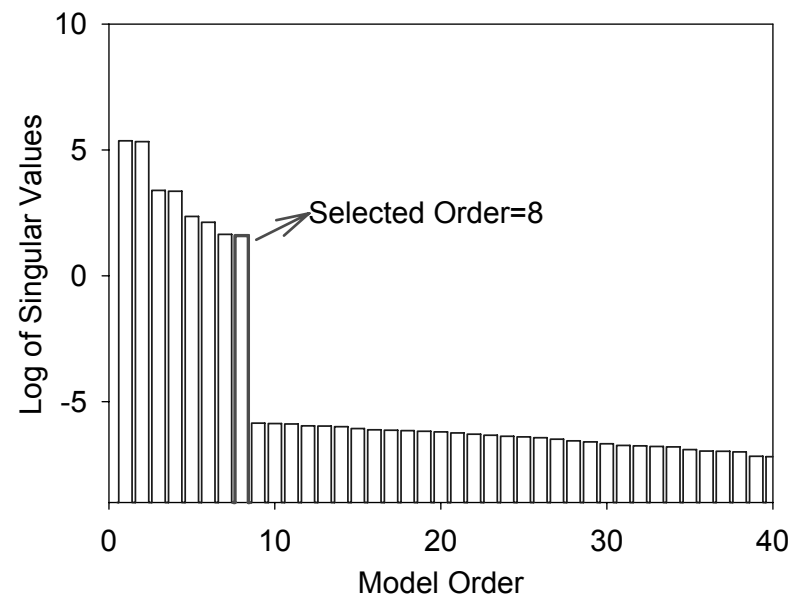

〈그림 8〉 상태방정식 차수 결정
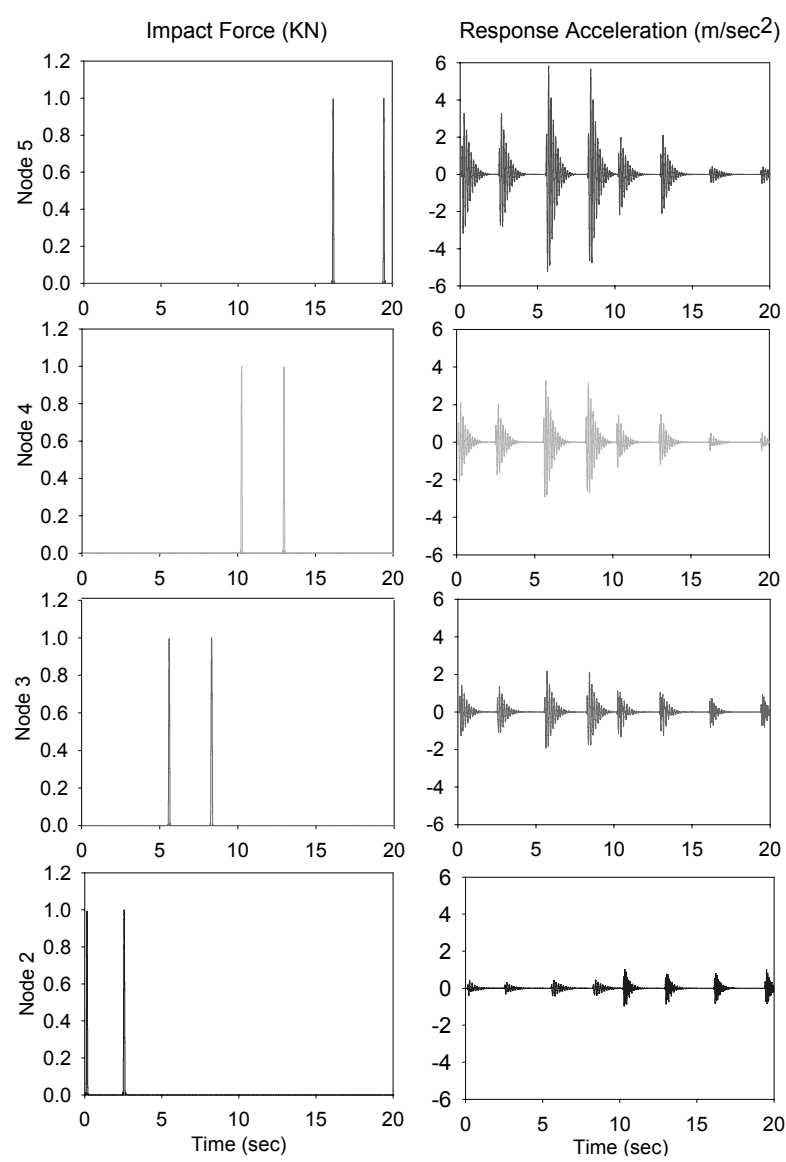

〈그림 9〉3차원 유한요소모델에 대한 충격해머와 가속도응답 신호

다. 모든 절점가속도에 대해서 제안된 기법이 실제 지진응 답을 매우 정확하게 예측하고 있음을 알 수 있다.

\section{3 계측 노이즈의 영향}

계측 노이즈의 지진응답예측에 대한 효과를 관찰하기 위 하여 4.1-2절의 프레임과 3차원 유한요소모델에 대하여 각각 계측오차 수치실험을 수행하였다. 충격해머(Impact Hammer) 와 가속도 계측치에 각각 $0.1 \%, 1 \%, 2 \%, 3 \%, 4 \%, 5 \%$ 


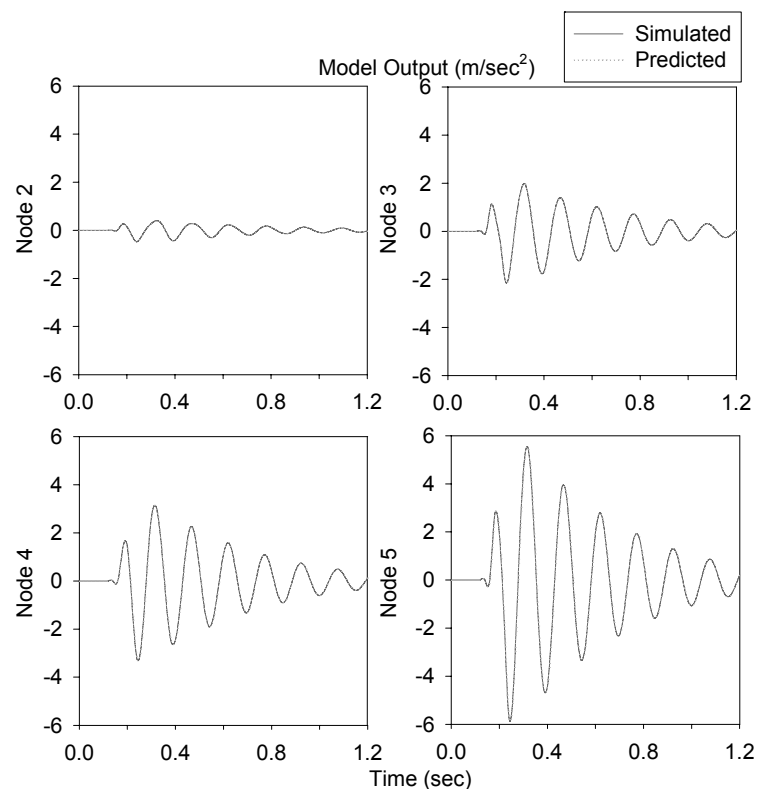

〈그림 10〉 규명된 이산시간 상태방정식의 적합도
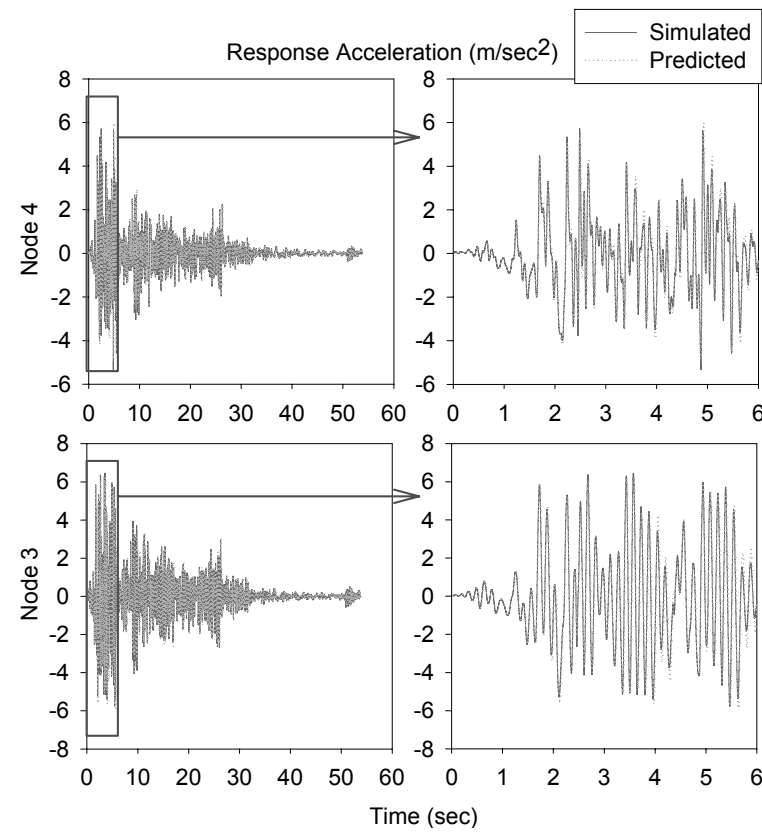

〈그림 11〉 제안된 방법으로 추정된 3차원 유한요소모델의 지진응답

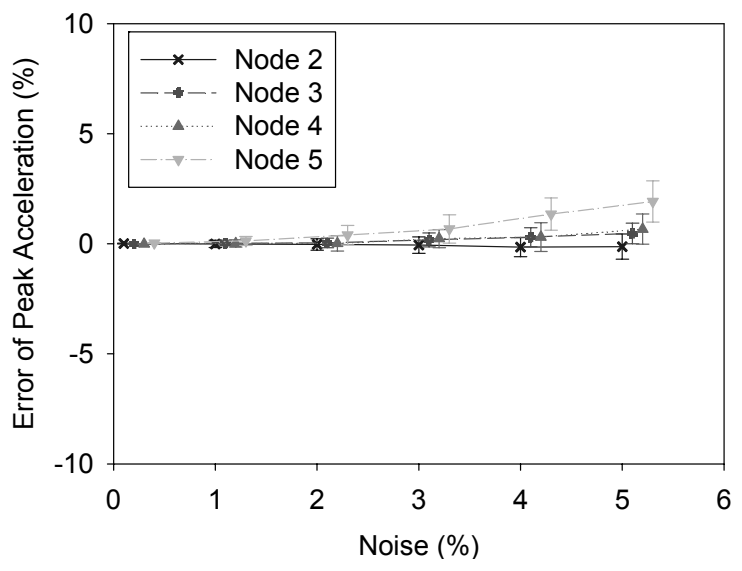

〈그림 12〉 프레임 모델에 대한 최대응답 추정오차

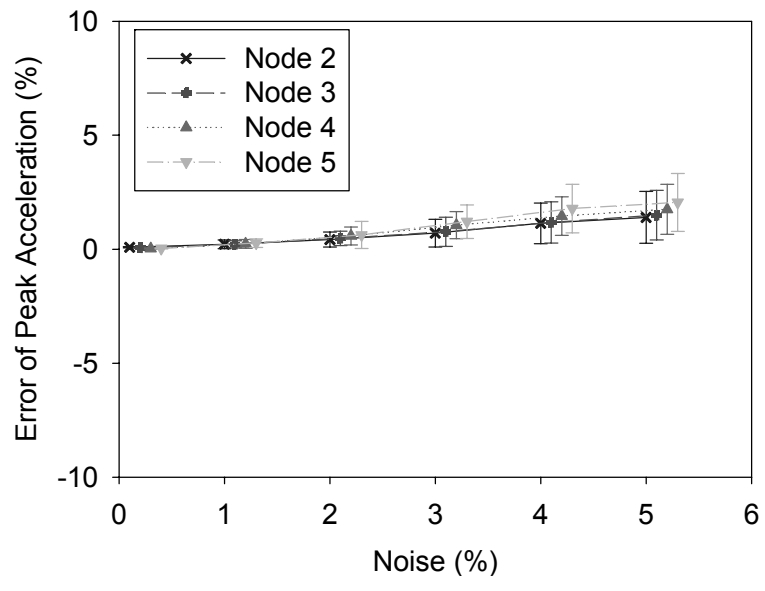

〈그림 13〉3차원 유한요소모델에 대한 최대응답 추정오차

RMS(Root Mean Square) 레벨의 백색 가우시안(White Gaussian) 노이즈를 첨가하고, 제안된 기법으로 지진응답을 추정하는 과정을 1000 회 반복하였다. 그림 12 와 그림 13 에 각각 프레 임과 3 차원 유한요소모델에 대한 최대응답 추정오차의 평균과 $1 \sigma$ (One-standard Deviation) 수준을 표시하였다. 노이즈 레 벨이 증가함에 따라서 편향오류(Bias Error)가 생기지 않고, 단지 $1 \sigma$ 편차 수준(Deviation Level)이 증가함을 관찰할 수 있다. 최대 $5 \% \mathrm{RMS}$ 노이즈에 대해서 추정오차가 $5 \%$ 보다 작은 매우 정확한 추정결과를 보여줌을 관찰 할 수 있다.

\section{5. 결 론}

본 연구에서는 운용 중 캐비닛의 내진성능평가를 위한 진 동시험를 이용한 지진응답예측기법을 제안하였다. 캐비닛구 조에 대한 직접적인 FEM 모델링이 여러 가지 모델링 오차를 수반할 수 있기 때문에, 지진하중에 대한 캐비닛 구조의 응답 을 바탕으로 상태방정식을 규명하였고, 이를 바탕으로 등가 지진하중에 대한 캐비닛 구조의 지진응답을 산정하였다. 본 방법은 캐비닛 구조의 입출력 관계를 블랙박스(Black-box) 로 모델링함으로써 FEM 모델을 사용할 경우 발생할 수 있는 여러 가지 모델링 오차를 극복 할 수 있었다.

프레임모델과 3차원 상세 FEM 모델에 대한 수치실험을 통하여 제안된 기법이 매우 정확하게 구조계의 지진응답을 예측함을 관찰 할 수 있었다. 또한, 측정 노이즈 시뮬레이션 을 통하여, 제안된 기법이 측정 노이즈에 대하여 강인함을 관찰하였다.

제안된 기법은 캐비닛 구조물의 질량 행렬 $M$ 을 추정하 는데 현실적인 어려움을 가질 수 있다. 운용 중 캐비닛 구조 물의 중량측정이 어렵기 때문에 설계도면을 바탕으로 질량 행렬을 추정해야 하는데, 추정치에 에러가 있다면 지진응답 예측치에 직접 비례적으로 오차가 발생하게 된다. 질량 행 
렬 $M$ 을 필요로 하지 않거나, 계측치를 통하여 추정하는 새 로운 기법의 개발이 바람직하다.

본 연구에서는 제안된 기법을 수치예제를 바탕으로 적용 성을 연구를 수행하였으나, 실제적인 캐비닛 구조물의 경우 경계조건의 문제, 비선형거동의 문제 등 여러 가지 난점이 발생할 수 있다. 제안된 기법의 실용성과 한계를 규명하기 위한 진동대 실험검증이 추후 연구로 필요하다고 판단된다.

\section{감사의 글}

이 논문은 지식경제부의 전력산업연구사업의 지원을 받 아 수행된 연구이며, 저자 일행은 지원에 감사드립니다.

\section{참 고 문 헌}

1. 조성국, 방기성, 김두기, 정영운, "현장 충격시험에 의한 고 리1호기 전기기기의 동특성분석,” 2008년도 한국지진공학회 학술발표회 논문집, 12 권, 2008, pp. 63-70,

2. 이계희, 김재민, 김상윤, “원자력 발전소 캐비닛구조물의 내진보강," 한국지진공학회 논문집, 제7권, 제4호, 2003, pp. 31-37.

3. 이경진, 함경원, 서용표, 윤현도, “원전 주제어실 3 차원 층 지진격리시스템의 진동대 실험 연구," 한국지진공학회 논 문집, 제12권, 제1호, 2003, pp. 31-37.

4. 이계희, 하동호, “ $\mu-\mathrm{GA}$ 를 이용한 원전 캐비닛구조물의 최 적감쇠보강," 한국지진공학회 논문집, 제9권, 제 1 호, 2005 , pp. 1-7.

5. NUREG-1030 : Seismic Qualification of Equipment in Operating Nuclear Power Plants (USI A-46), February 1987.

6. NUREG-1211 : Regulatory Analysis for Resolution of Unresolved Safety Issue A-46, Seismic Qualification of Equipment in Operating Plants, February 1987.

7. Seismic Qualification Utility Group (SQUG), Generic
Implementation Procedure for Seismic Verification of Nuclear Plant Equipment, SQUP, 1992.

8. Electrical Power Research Institute (EPRI), Guidelines for Development of In-Cabinet Amplified Response Spectra for Electrical Benchboards and Panels, EPRI, NP-7146-SL, 1990.

9. Electrical Power Research Institute (EPRI), Guidelines for Development of In-Cabinet Demand for Devices Mounted in Electrical Cabinets, EPRI, NP-7146-SL R1, 1995.

10. Overschee, P. V. and Moor, B. D. "N4SID: Subspace algorithms for the identification of combined deterministicstochastic systems," Automatica 30(1), special issue on statistical signal processing and control, 1994, pp. 75-93.

11. Ljung, L., System Identification: Theory for the User, second Ed., Prentice-Hall, NJ 07458, USA, 1999.

12. MIDAS Civil 2006 Online Manual, MIDAS Information Technology Co., Ltd. 2005.

13. Gupta, A., Rustogi, S. K., and Gupta, A. K., "Ritz vector approach for evaluating incabinet response spectra," Nuclear Engineering and Design, 190, 1999, pp. 255-272.

14. Yang, J. and Gupta, A., "Ritz vector approach forstaticand dynamic analysisof plateswith edge beams," Journal of Sound and Vibration, 253(2), 2002, pp. 373-388.

15. Yang, J. and Gupta, A., "Modified Ritz vector approach for dynamic properties of electrical cabinets and control panels," Nuclear Engineering and Design, 217, 2002, pp. 49-62.

16. Yang, J, Rustogi, S. K., and Gupta, A., "Rocking stiffness of mounting arrangements in electrical cabinets and control panels," Nuclear Engineering and Design, 219, 2002, pp. 127-141.

17. Rustogi1, S. and Gupta, A., "Modeling the Dynamic Behavior of Electrical Cabinets and Control Panels: Experimental and Analytical Results," Journal of Structural Engineering, Vol. 130, No. 3, March 1, 2004. 